\title{
Developmental changes in gonadotropin-inhibitory hormone in the Japanese quail (Coturnix japonica) hypothalamo-hypophysial system
}

\author{
T Ubuka, M Ueno, K Ukena and K Tsutsui \\ Laboratory of Brain Science, Faculty of Integrated Arts and Sciences, Hiroshima University, Higashi-Hiroshima 739-8521, Japan and Core Research for \\ Evolutional Science and Technology (CREST), Japan Science and Technology Corporation, Tokyo 150-0002, Japan \\ (Requests for offprints should be addressed to K Tsutsui; Email tsutsui@hiroshima-u.ac.jp)
}

\begin{abstract}
We previously isolated a novel dodecapeptide containing a C-terminal -Arg-Phe- $\mathrm{NH}_{2}$ sequence, SIKPSAYLPLRF$\mathrm{NH}_{2}$ (RFamide peptide), from the Japanese quail (Coturnix japonica) brain. This novel quail peptide was shown to be located in neurons of the paraventricular nucleus (PVN) and their terminals in the median eminence (ME), and to decrease gonadotropin release from cultured anterior pituitary in adult birds. We therefore designated this peptide gonadotropin-inhibitory hormone $(\mathrm{GnIH})$. Furthermore, a cDNA encoding the GnIH precursor polypeptide has been characterized. To understand the physiological roles of this peptide, in the present study we analyzed developmental changes in the expressions of GnIH precursor mRNA and the mature peptide GnIH during embryonic and posthatch ages in the quail diencephalon including the PVN and ME. GnIH
\end{abstract}

precursor mRNA was expressed in the diencephalon on embryonic day 10 (E10) and showed a significant increase on E17, just before hatch. GnIH was also detected in the diencephalon on E10 and increased significantly around hatch. Subsequently, the diencephalic GnIH content decreased temporarily, and again increased progressively until adulthood. GnIH-like immunoreactive (GnIH-ir) neurons were localized in the PVN on E10, but GnIH-ir fibers did not extend to the ME. However, GnIH-ir neurons increased in the PVN on E17, just before hatch, and GnIH-ir fibers extended to the external layer of the $\mathrm{ME}$, as in adulthood. These results suggest that GnIH begins its function around hatch and acts as a hypothalamic factor to regulate gonadotropin release in the bird.

Journal of Endocrinology (2003) 178, 311-318

\section{Introduction}

We have previously isolated a novel dodecapeptide containing a C-terminal -Arg-Phe- $\mathrm{NH}_{2}$ sequence, SIKPSAYLPLRF-NH $\mathrm{N}_{2}$ (RFamide peptide), from the brain of the Japanese quail (Coturnix japonica) (Tsutsui et al. 2000). The striking feature of the novel quail peptide is that it exerts a specific inhibitory effect on the release of gonadotropins from the cultured quail anterior pituitary in a dose-dependent manner with a threshold of 1-10 nM (Tsutsui et al. 2000). Furthermore, cell bodies and terminals containing this peptide were localized immunocytochemically in the paraventricular nucleus (PVN) and median eminence (ME) respectively (Tsutsui et al. 2000). On the basis of these findings, we proposed that this quail peptide acts as a novel inhibitory factor of gonadotropin release in the hypothalamo-hypophysial system in birds and named the peptide gonadotropin-inhibitory hormone (GnIH) (Tsutsui et al. 2000). More recently, a cDNA encoding the GnIH precursor polypeptide has also been characterized in the quail brain (Satake et al. 2001).
In this present study, to understand the physiological roles and biological significance of $\mathrm{GnIH}$, we clarified developmental changes in the expressions of GnIH precursor mRNA and the mature peptide GnIH in the quail diencephalon including the PVN and ME during embryonic and posthatch ages by the methods of competitive PCR and ELISA. This study further carried out immunocytochemical analysis to reveal morphological changes in GnIH neurons in the hypothalamo-hypophysial system during development.

\section{Materials and Methods}

Animals and tissue samples

Mixed sex embryos and posthatch males of the Japanese quail (Coturnix japonica) at various ages were used in this study. Fertilized eggs were incubated under daily photoperiods of $16 \mathrm{~h}$ light: $8 \mathrm{~h}$ darkness cycles (long day; lights on at $0700 \mathrm{~h}$ ), and embryos usually hatched at 18 days 
of incubation. During posthatch development, we used males reared under long-day photoperiods, because no sex differences in the expressions of $\mathrm{GnIH}$ precursor mRNA and GnIH in the PVN have been observed in this bird (Tsutsui et al. 2000, Ukena et al. 2003). Posthatch males were housed in a temperature-controlled room, and given quail food and tap water freely. The experimental protocol was approved in accordance with the Guide for the Care and Use of Laboratory Animals prepared by Hiroshima University (Higashi-Hiroshima, Japan).

\section{Competitive PCR analysis of $\mathrm{GnIH}$ precursor $m R N A$}

To quantify the mRNA encoding GnIH precursor polypeptide in the diencephalon, competitive PCR analysis was performed using embryos at different ages (embryonic days (E) 10,14, 17) and posthatch males at different ages (posthatch days $(\mathrm{P}) 1,7,21,49,84)$. All embryos and posthatch males were killed by decapitation between 1000 and $1200 \mathrm{~h}$. The diencephalon including GnIH neurons in the PVN and their terminals in the ME (Tsutsui et al. 2000, Ukena et al. 2003) was carefully removed using fine forceps under a dissecting microscope, snap-frozen immediately in liquid nitrogen and used for RNA isolation. Total RNA (including rRNA and mRNA) from the diencephalon was isolated by the Sepasol extraction method, according to the manufacturer's instructions (Sepasol-RNA I Super; Nacalai tesque, Kyoto, Japan). Total RNA concentrations were measured with accurate spectrophotometric quantification (GeneQuant pro's' RNA/DNA Calculator; Amersham Pharmacia Biotech). They were reverse transcribed using oligo(deoxythymidine) primer and reverse transcriptase in a $30 \mu \mathrm{l}$ reaction volume for $2 \mathrm{~h}$ at $37^{\circ} \mathrm{C}$. The reaction mixture was composed of $15 \mu \mathrm{g}$ total RNA, $50 \mathrm{mM}$ Tris $-\mathrm{HCl}$ (pH 8.3), $75 \mathrm{mM} \mathrm{KCl}, 3 \mathrm{mM} \mathrm{MgCl} 2,10 \mathrm{mM}$ dithiothreitol, $0.5 \mathrm{mM}$ deoxynucleoside triphosphate mix, $0.25 \mu \mathrm{g}$ oligo(deoxythymidine)12-18 (Amersham Pharmacia Biotech), $15 \mathrm{U}$ ribonuclease inhibitor (Wako, Osaka, Japan), and $150 \mathrm{U}$ Moloney murine leukemia virus transcriptase (Life Technologies, Burlington, Canada). After the reaction was stopped by incubation at $65^{\circ} \mathrm{C}$ for $10 \mathrm{~min}$, the cDNA was ethanol precipitated and redissolved in $15 \mu$ distilled water. These procedures were made in parallel for all samples with the same working solution to minimize the tube-to-tube variation.

Competitor DNA was produced by PCR using cDNA generated from the cerebrum and following primers. Sense primer, 5'-GAGCTTCCTAACTGAGCTTCAGCTAT GTTGGTGATGAAGC-3' and antisense primer, 5'CACGGTGCATCTTTTCTGGGGGTGAAGCTGTA GCCTCTCT-3'. Using these primers, a native $450 \mathrm{bp}$ fragment of $\beta$-actin gene (nucleotides 91-540; AF199488) with additional $20 \mathrm{bp}$ fragments of $\mathrm{GnIH}$ precursor (underlined) (Satake et al. 2001) where primers for com-
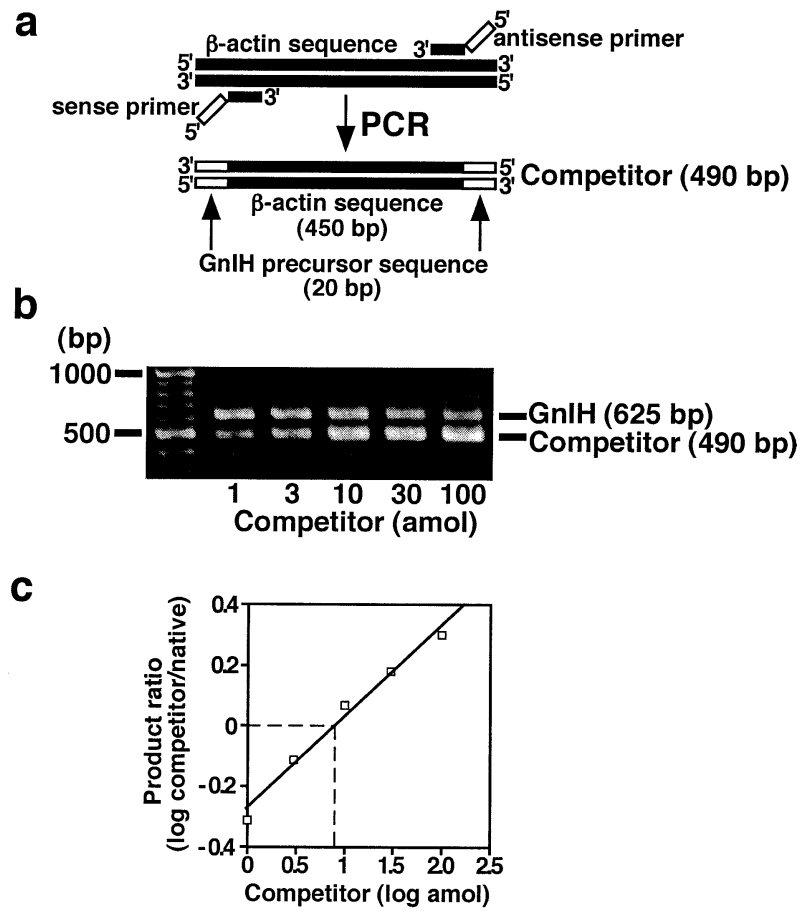

Figure 1 Schematic representation of a competitive PCR method. (a) The competitor (490 bp) was produced by PCR using cDNA and $40 \mathrm{bp}$ primers, which have the sequences corresponding to GnlH precursor sequence (20 bp, white box) and $\beta$-actin sequence (20 bp, black box) serially. Produced competitor had 20 bp of GnlH precursor sequences (white box) on its $5^{\prime}$ and $3^{\prime}$ ends where primers for competitive PCR anneal. (b) Image of the ethidium bromide-stained $1 \cdot 5 \%$ agarose gel showing competitive PCR products. Relative intensities of the bands of $\mathrm{GnlH}$ precursor cDNA product $(625 \mathrm{bp})$ were inversely proportional to varying dilutions $(1,3,10,30$ and $100 \mathrm{amol})$ of the competitor, which were co-amplified (490 bp). (c) Log/log plots using the data from the gel in (b). After the intensity data of the competitive PCR products were normalized for the size, product ratios (log competitor/native) were plotted against the competitor standard (log amol). The amount of GnlH precursor cDNA was estimated calculating from the $x$-axis value where the product ratio (log competitor/native) becomes zero.

petitive PCR anneal were generated. Schematic representation is shown in Fig. 1a. Because GnIH mRNA was not expressed in the cerebrum (Satake et al. 2001), cDNA generated from this brain region was used, and primer annealing to $\mathrm{GnIH}$ precursor cDNA was prevented. The PCR mixture contained cDNA, $20 \mathrm{mM}$ Tris- $\mathrm{HCl}(\mathrm{pH}$ $8 \cdot 0), 100 \mathrm{mM} \mathrm{KCl}, 0 \cdot 1 \%$ Triton X-100, $1.5 \mathrm{mM} \mathrm{MgCl}_{2}$, $0.2 \mathrm{mM}$ deoxynucleoside triphosphate mix, $0.5 \mu \mathrm{M}$ of each primer, and $1 \mathrm{U}$ Gene Taq DNA polymerase (Wako). After denaturation at $94{ }^{\circ} \mathrm{C}$ for 3 min, the mixture was subjected to 30 thermal cycling in a programmed temperature control system (PC-808; ASTEC, Fukuoka, Japan) as follows: denaturation at $94{ }^{\circ} \mathrm{C}$ for $1 \mathrm{~min}$, primer annealing at $60{ }^{\circ} \mathrm{C}$ for $1 \mathrm{~min}$, and extension at $72{ }^{\circ} \mathrm{C}$ 
for $1 \mathrm{~min}$. After the thermal cycling, the mixture was additionally incubated at $72{ }^{\circ} \mathrm{C}$ for $3 \mathrm{~min}$ and purified by spin column (MicroSpin S-400HR Column; Amersham Pharmacia Biotech). A $5 \mu$ l aliquot was electrophoresed through a $1.5 \%$ agarose gel for sizing. Products were spectrometrically quantified and aliquots were used as standards for competitive PCR analysis.

For competitive PCR, an aliquot of the cDNA solution corresponding to $1 \mu \mathrm{g}$ of the initial total RNA of each diencephalon and competitor standard $(1,3,10,30$ and $100 \mathrm{amol} /$ tube) were used as templates in a $26 \mu \mathrm{l}$ reaction mixture. Oligonucleotides used as competitive PCR primers based on nucleotide sequences of quail $\mathrm{GnIH}$ precursor polypeptide (Satake et al. 2001) were as follows: sense primer, 5'-GAGCTTCCTAACTGAGCTTC-3' (identical with nucleotides 10-29 in Satake et al. (2001)) and antisense primer, 5'-CACGGTGCATCTTTTCT GGG-3' (complementary to nucleotides 615-634 in Satake et al. (2001)). The sense and antisense primers amplified a native $625 \mathrm{bp}$ fragment of the GnIH precursor gene, and co-amplified competitor standard diluted in the reaction mixture. PCR was performed after denaturation at $94{ }^{\circ} \mathrm{C}$ for $3 \mathrm{~min}$, the mixture was subjected to 35 thermal cycling in a programmed temperature control system as follows: denaturation at $94^{\circ} \mathrm{C}$ for $1 \mathrm{~min}$, primer annealing at $54^{\circ} \mathrm{C}$ for $1 \mathrm{~min}$, and extension at $72{ }^{\circ} \mathrm{C}$ for $1 \mathrm{~min}$. After the thermal cycling, the mixture was additionally incubated at $72{ }^{\circ} \mathrm{C}$ for $10 \mathrm{~min}$. Then a $5 \mu \mathrm{l}$ aliquot of each sample was electrophoresed through a $1.5 \%$ agarose gel. PCR products were quantified by fluorescence of ethidium bromide on a $3 \mathrm{UV}$ Transilluminator (UVP, Inc., Upland, CA, USA) and subsequent twodimensional analysis of the gel image with an NIH Image software package. Intensity data so derived were subjected to quantitative analysis to calculate the concentration of the corresponding GnIH precursor mRNA. Briefly, raw intensity data were adjusted for proportionate size of the native and competitor product, and the product ratio (log competitor/native) was plotted against the competitor standard $(\log$ amol). Figure $1 \mathrm{~b}$ and $\mathrm{c}$ shows such $\mathrm{a}$ densitometric analysis of the products on one specimen. In the example illustrated in Fig. 1b, the amount of added competitor increases logarithmically going rightward across the lanes, and is accompanied by an increase in the PCR product ratio (competitor/native). In Fig. 1c, the product ratio (log competitor/native) is plotted against each competitor amount (log amol). Across this competitor concentration range, the point at which there are equal quantities of the products (point of equivalence) is crossed and the plot approximates to linear. The point of equivalence can thus be estimated accurately. This allows a quantitative estimate of GnIH precursor cDNA concentration in the reverse-transcribed sample, which is derived from $1 \mu \mathrm{g}$ total RNA. In the example in Fig. 1c, the point of equivalence shows that the concentration of $\mathrm{GnIH}$ precursor cDNA is $8 \cdot 1 \mathrm{amol} / \mu \mathrm{g}$ total RNA.

\section{Peptide extraction and ELISA of $\mathrm{GnIH}$}

The concentration and content of GnIH in the diencephalon were quantified by a competitive ELISA method using the antiserum raised against $\mathrm{GnIH}$, according to our previous method (Tsutsui et al. 2000). Embryos (E10, 14, 17) and posthatch males (P1, 7, 21, 49, 84) at different developmental ages were killed by decapitation between 1000 and $1200 \mathrm{~h}$. The diencephalon at each age was carefully removed, snap-frozen immediately in liquid nitrogen and used for peptide extraction.

Peptides were extracted according to our previous methods (Li et al. 1996, Sakamoto et al. 2000, Ubuka et al. 2001). Frozen diencephalic samples were boiled for $7 \mathrm{~min}$ and homogenized in 5\% acetic acid using a homogenizer (Ultra-Turrax T8 IKA; Labortechnik, Staufen, Germany). The homogenate was centrifuged at $16000 \mathrm{~g}$ for $30 \mathrm{~min}$ at $4{ }^{\circ} \mathrm{C}$. The supernatant was collected into a tube, and the resulting precipitate was further homogenized and centrifuged, and the supernatant was collected again. The two supernatants were pooled and forced through a disposable C-18 cartridge (Sep-Pak Vac 1cc; Waters, Milford, MA, USA). The retained material was then eluted with $60 \%$ methanol. The pooled eluate was concentrated in a vacuum evaporator at $40{ }^{\circ} \mathrm{C}$, passed through disposable Ultrafree-MC Centrifugal Filter Units (Millipore, Bedford, MA, USA) and subjected to competitive ELISA, as previously described (Tsutsui et al. 2000). In brief, different concentrations of $\mathrm{GnIH}(1-1000 \mathrm{pmol} / \mathrm{ml})$ and adjusted tissue extracts were added with the antiserum against $\mathrm{GnIH}$ (1:1000 dilution) to each antigen-coated well of a 96-well microplate (Multi-well plate for ELISA, H-Type; Sumitomo Bakelite Co., Ltd, Tokyo, Japan) and incubated for $1 \mathrm{~h}$ at $37^{\circ} \mathrm{C}$. The antiserum against $\mathrm{GnIH}$ was raised in a rabbit using synthetic GnIH linked to keyhole limpet hemocyanin (Tsutsui et al. 2000). It has been previously confirmed that the antiserum cross-reacts with GnIH on the basis of competitive ELISA (Tsutsui et al. 2000). After the reaction with alkaline phosphataselabeled goat anti-rabbit IgG, immunoreactive products were obtained in a substrate solution of $p$ nitrophenylphosphate, and the absorbance was measured at $415 \mathrm{~nm}$ on a microtiter plate reader (MTP-120; Corona Electric, Ibaraki, Japan).

\section{Immunocytochemical analysis of $\mathrm{GnIH}$}

Embryos at different developmental ages (E10 and 17) and adult males (P84) were killed by decapitation. Brains were carefully removed and immediately immersion-fixed in Bouin's solution for $14-16 \mathrm{~h}$ at $4{ }^{\circ} \mathrm{C}$ before immunocytochemical procedures. Subsequently, brain tissues were placed in refrigerated 30\% sucrose in PBS $(10 \mathrm{mM}$ phosphate buffer and $0.14 \mathrm{M} \mathrm{NaCl} ; \mathrm{pH} 7 \cdot 3$ ) and frozensectioned frontally at $20 \mu \mathrm{m}$ thickness on a cryostat at $-20{ }^{\circ} \mathrm{C}$. 
For the immunocytochemistry of GnIH (Tsutsui et al. 2000, Ukena et al. 2003), endogenous peroxidase activity was eliminated from the sections by incubation with $0 \cdot 3 \%$ $\mathrm{H}_{2} \mathrm{O}_{2}$ in absolute methanol for $10 \mathrm{~min}$. After blocking nonspecific binding components with $1 \%$ normal goat serum and $1 \%$ BSA in PBS containing 0.3\% Triton X-100 for $30 \mathrm{~min}$ at room temperature, the sections were immersed in the primary antiserum directed against $\mathrm{GnIH}$ at a dilution of 1:1000 for $16-20 \mathrm{~h}$ at $4{ }^{\circ} \mathrm{C}$. Several concentrations of the antiserum were examined, and a solution of 1:1000 proved the most satisfactory (Tsutsui et al. 2000, Ukena et al. 2003). Immunoreactive products were detected with an $\mathrm{ABC}$ kit (Vectastain Elite Kit; Vector Laboratories, Inc., Burlingame, CA, USA), followed by diaminobenzidine reaction according to our previous method (Tsutsui et al. 2000, Ukena et al. 2003).

Control for specificity of the immunocytochemistry of GnIH was performed by pre-adsorbing the working dilution of the primary antiserum with a saturating concentration of the antigen $(10 \mu \mathrm{g} \mathrm{GnIH} / \mathrm{ml})$. The sections were incubated with this control serum in a similar way to the $\mathrm{GnIH}$ antiserum. The localization of immunoreactive cell bodies and fibers in the diencephalon was studied using an Olympus BH-2 microscope.

\section{Statistical analysis}

Results for the expression of GnIH precursor mRNA and the concentration and content of GnIH in the diencephalon during development were expressed as means \pm S.E.M., and were analyzed for significance of difference by a one-way ANOVA. If significant in ANOVA, the analysis was followed by a Duncan's multiple range test (Bliss 1967).

\section{Results}

Changes in the expression of $G n I H$ precursor $m R N A$ in the diencephalon during development

The expression of $\mathrm{GnIH}$ precursor mRNA on a unit weight basis $(\mu \mathrm{g})$ of total RNA was low on E10 and E14, and increased significantly on E17, just before hatch $(P<0 \cdot 01$, E17 vs other embryonic and posthatch ages; Fig. 2 ). Subsequently, the expression of $\mathrm{GnIH}$ precursor mRNA on a unit weight of total RNA decreased after hatching and maintained the low level during posthatch development (Fig. 2).

Changes in the concentration and content of $\mathrm{GnIH}$ in the diencephalon during development

Changes in the concentration and content of GnIH in the diencephalon were measured during embryonic and posthatch ages by a competitive ELISA using the antiserum

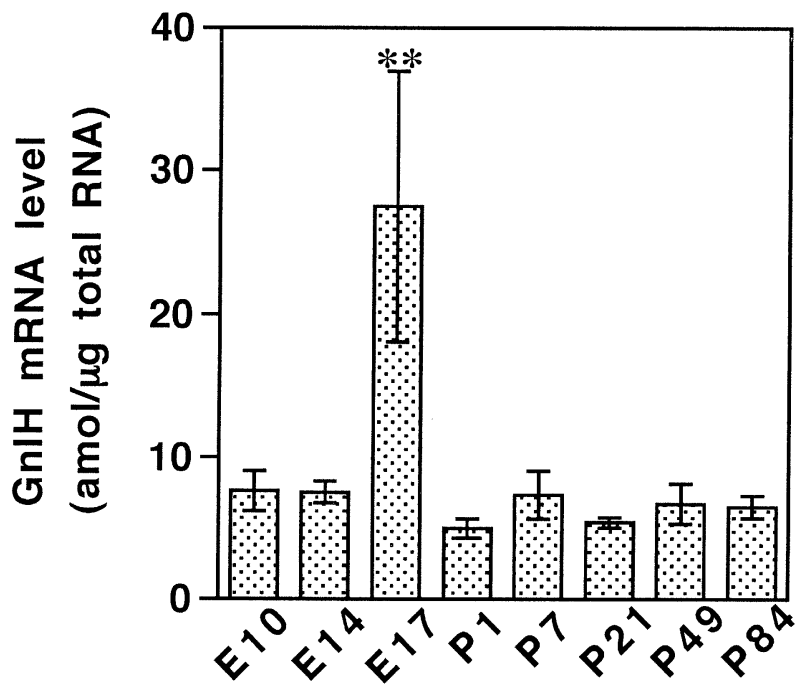

Figure 2 Changes in the expression of GnlH precursor mRNA in the diencephalon during development. Each column and vertical line represents the mean \pm S.E.M. (five samples at each age: one sample from one quail). ${ }^{*} P<0 \cdot 01 \mathrm{E} 17$ vs other embryonic and posthatch ages. Duncan's multiple range test.

raised against $\mathrm{GnIH}$, a mature peptide. The concentration of $\mathrm{GnIH}$ on a unit weight basis $(\mathrm{mg})$ of diencephalon was low on E10 and E14, but increased significantly on E17 and P1 $(P<0 \cdot 01$, E17, P1 vs E10, E14; Fig. 3a). Subsequently, the GnIH concentration decreased on P7 $(P<0 \cdot 01, \mathrm{P} 7$ vs $\mathrm{E} 17, \mathrm{P} 1)$ and tended to increase during posthatch development (Fig. 3a). Similarly, a significant increase in the $\mathrm{GnIH}$ content per diencephalon was observed on E17 and P1 $(P<0 \cdot 01, \mathrm{E} 17, \mathrm{P} 1$ vs E10, E14; Fig. 3b). The GnIH content also decreased on P7 $(P<0 \cdot 01, \mathrm{P} 7$ vs $\mathrm{E} 17, \mathrm{P} 1)$ and significantly increased thereafter $(P<0 \cdot 01, \mathrm{P} 49, \mathrm{P} 84$ vs P7; Fig. $3 \mathrm{~b})$, due to an increase in the diencephalic tissue.

Morphological changes in GnIH neurons in the hypothalamo-hypophysial system during development

Morphological changes in GnIH-like immunoreactive (GnIH-ir) cell bodies and fibers in the PVN were first analyzed by immunocytochemistry using the antiserum raised against GnIH. As shown in Fig. 4a, an intense immunoreaction for $\mathrm{GnIH}$ was found only in the PVN in the diencephalon on E10. However, GnIH-ir cell bodies were small and rod- or spindle-shaped and sparsely distributed in the PVN (Fig. 4a). Some of immunoreactive cells tended to be unipolar or bipolar, but their fibers were short (Fig. 4a). On E17, GnIH-ir cells increased and concentrated in the PVN (Fig. 4c). Most of the immunoreactive cell bodies on E17 became larger than those on E10 and more round shaped (Fig. 4a and c). In addition, many GnIH-ir fibers were emanating from immunoreactive cells on E17 (Fig. 4c), indicating that neural networks 

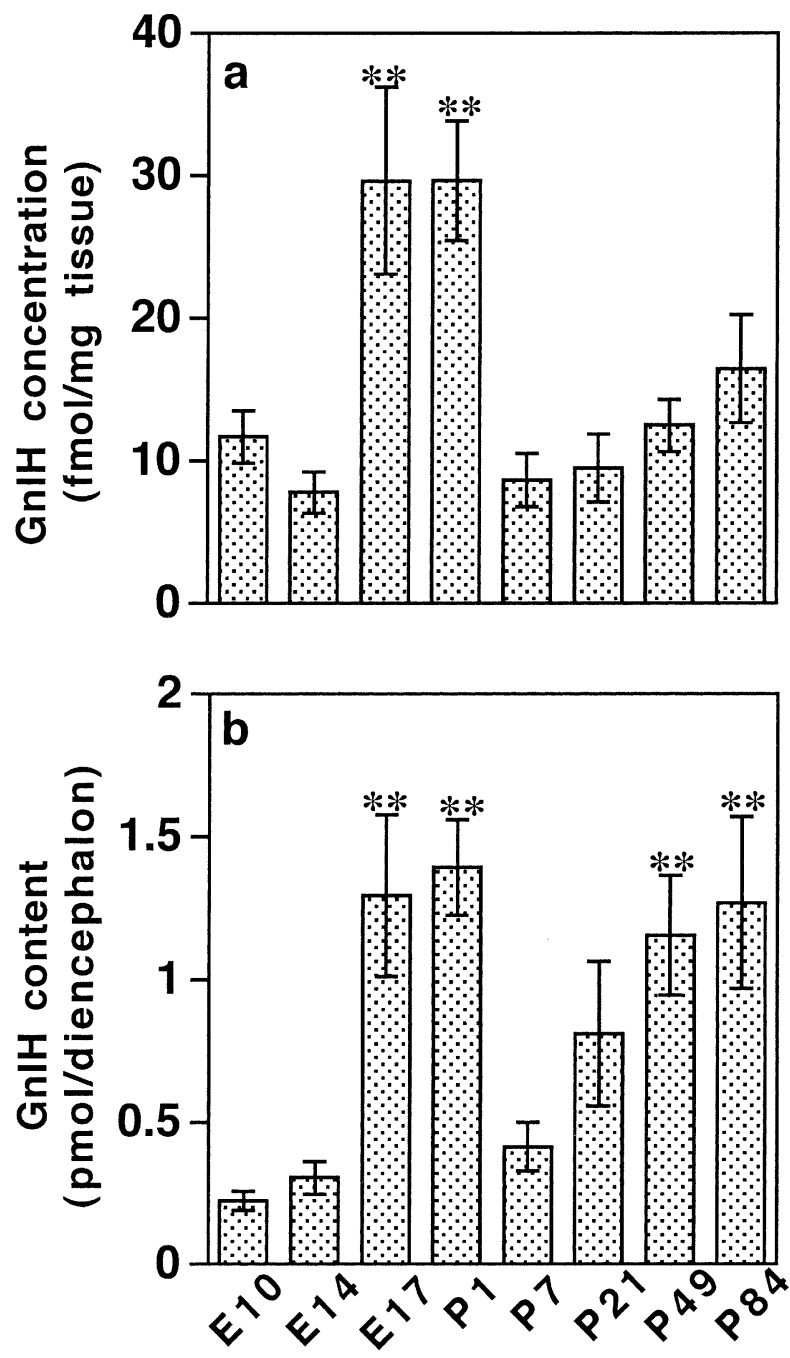

Figure 3 Changes in the GnlH concentration (a) and content (b) in the diencephalon during development. (a) Each column and vertical line represents the mean \pm S.E.M. (six samples at each age: one sample from one quail). ${ }^{*} P<0 \cdot 01 \mathrm{E} 17, \mathrm{P} 1$ vs E10, E14, P7, P21, P49, P84. Duncan's multiple range test. (b) Each column and vertical line represents the mean \pm S.E.M. (six samples in each age: one sample from one quail). ${ }^{*} P<0 \cdot 01 \mathrm{E} 17, \mathrm{P} 1$ vs E10, E14, P7; P49, P84 vs E10, E14, P7. Duncan's multiple range test.

appear to be developed. On P84, an intense immunoreaction for $\mathrm{GnIH}$ was also observed in the large cell bodies, which were distributed throughout the PVN (Fig. 4e). Many GnIH-ir fibers were also distributed in the PVN (Fig. 4e). Pre-adsorbing the antiserum (1:1000 dilution) with an excess of $\mathrm{GnIH}$ at a concentration of $10 \mu \mathrm{g} / \mathrm{ml}$ resulted in a complete absence of the immunoreaction in all of the positively stained cell bodies and fibers in the PVN at each age (Fig. $4 b, d$ and $\mathrm{f}$ ).

We further characterized morphological changes in GnIH-ir fibers in the ME, because we have previously confirmed that GnIH-containing PVN neurons extend

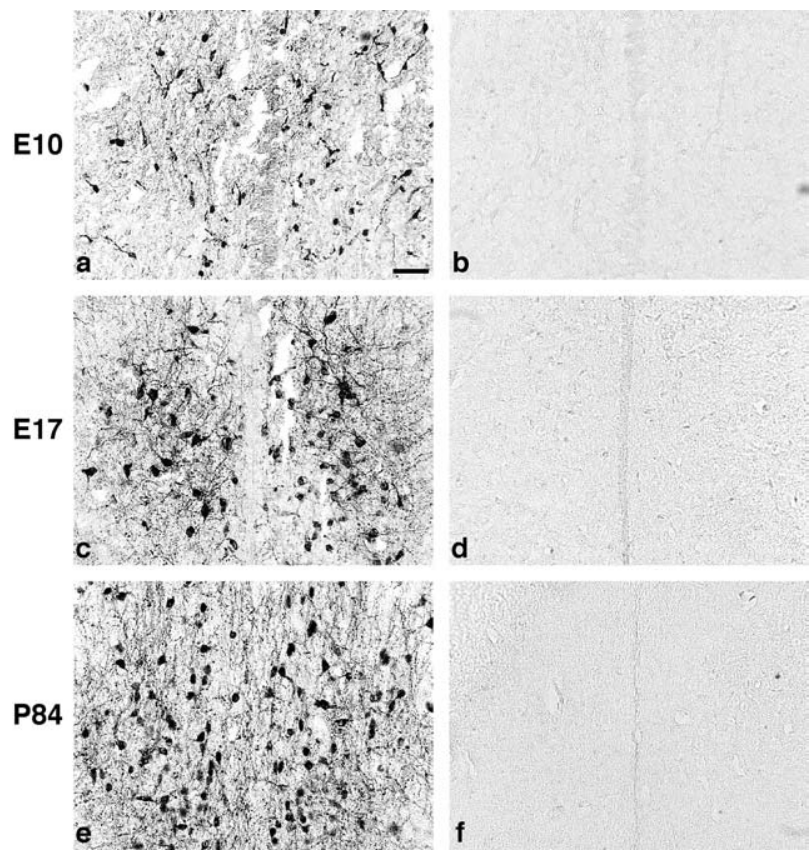

Figure 4 Immunocytochemical staining with the antiserum to $\mathrm{GnIH}$ (a, c, e) or with the antiserum pre-incubated with a saturating concentration of synthetic GnIH (b, d, f) in the quail PVN on E10 ( $a$ and b), E17 (c and d) and P84 (e and f). (a-f) are at the same magnification (bar represents $50 \mu \mathrm{m}$ ). Similar results were obtained in repeated experiments using four different birds at each age.

their terminals into the ME in adult birds (Tsutsui et al. 2000, Ukena et al. 2003). On E10, only few GnIH-ir fibers were observed in the medial layer of the ME (Fig. 5a). Unlike E10, abundant GnIH-ir fibers were observed in the medial and external layers of the ME on E17 (Fig. 5c). These fibers showed a characteristic palisade-like structure and terminated on the external surface of the ME (Fig. 5c). GnIH-ir fibers became more numerous in the medial and external layers and terminated on the external surface on P84 (Fig. 5e). Pre-adsorption control sections also exhibited no immunoreactivity in the $\mathrm{ME}$ at each age (Fig. 5b, d and f). These immunocytochemical experiments in the diencephalon including the PVN and ME were repeated four times using different birds at each developmental age and indicated similar results.

\section{Discussion}

GnIH precursor mRNA showed a significant increase in the diencephalon on E17, just before hatch. Similarly, its translated product GnIH increased significantly on E17 and P1. These results suggest that GnIH neuronal function may increase around hatch. This hypothesis postulated here is confirmed by the present immunocytochemical 


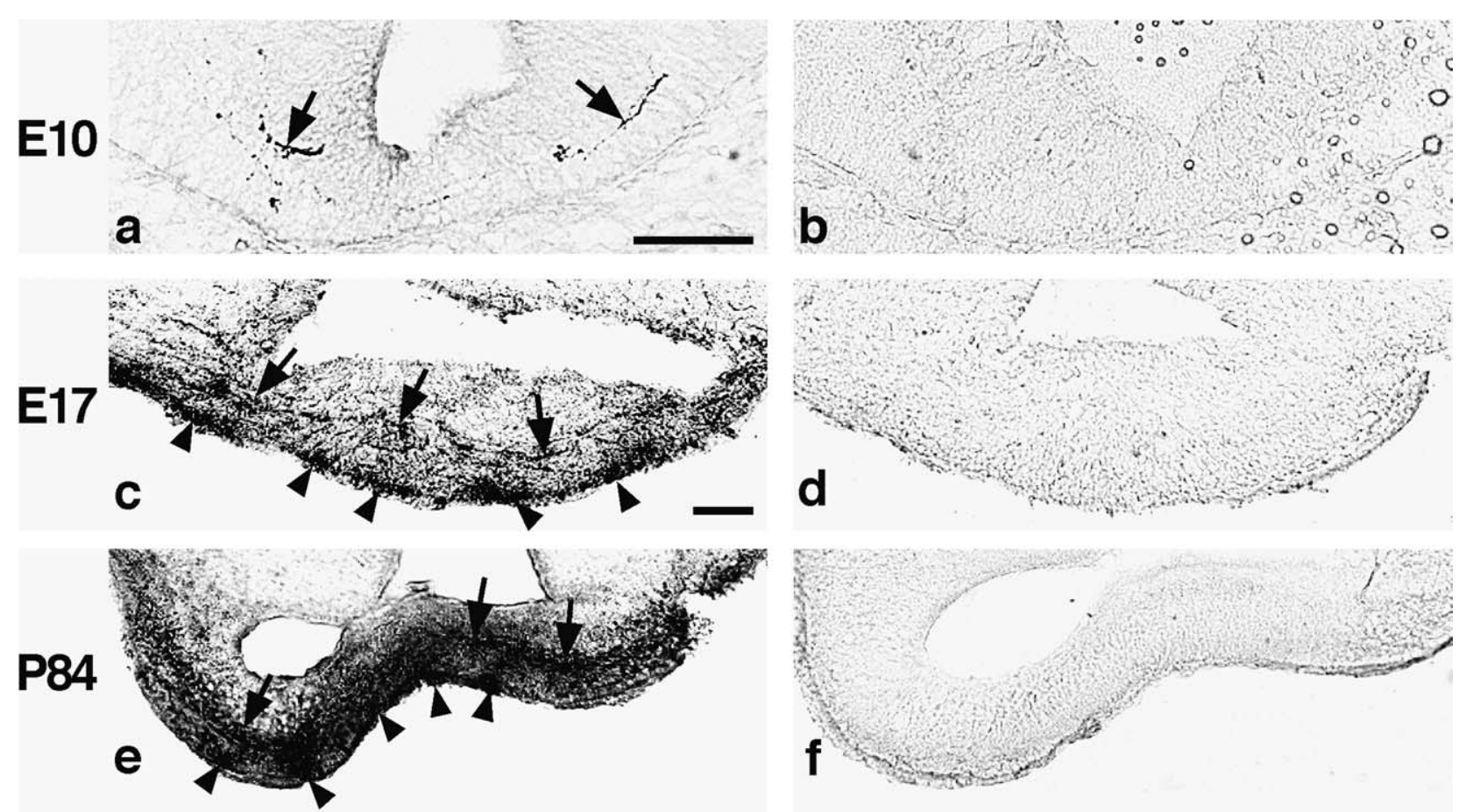

Figure 5 Immunocytochemical staining with the antiserum to $\mathrm{GnIH}(\mathrm{a}, \mathrm{c}, \mathrm{e})$ or with the antiserum pre-incubated with a saturating concentration of synthetic $\mathrm{GnIH}(\mathrm{b}, \mathrm{d}, \mathrm{f})$ in the quail ME on E10 (a, b), E17 (c, d) and P84 (e, f). (a, b) are at the same magnification, and (c-f) are at the same magnification (bars represent $50 \mu \mathrm{m}$ ). Arrows (in a, c and e) indicate $\mathrm{GnlH}$-ir fibers in the medial layer of the ME. Arrowheads (in c and e) indicate GnlH-ir fibers which terminate on the external surface of the ME. Similar results were obtained in repeated experiments using four different birds at each age.

analysis showing morphological changes in GnIHcontaining PVN neurons during development. GnIH-ir neurons in the PVN were immature on E10, the middle embryonic period, judging from morphological characteristics of their small cell bodies and short fibers. In contrast, GnIH-ir PVN neurons appear to be mature on E17, just before hatch, because abundant large cell bodies and well-developed fibers were detected. Interestingly, abundant GnIH-ir fibers were also found in the medial and external layers of the ME at the same period. Furthermore, some of the GnIH-ir fibers terminated on the external surface of the ME. We have previously demonstrated that in the adult quail many fibers emanating from GnIHcontaining PVN neurons terminate in the external layer of the ME (Tsutsui et al. 2000, Ukena et al. 2003). Accordingly, it is considered that GnIH-containing PVN neurons first innervate the ME around hatch. GnIH secretion from the terminals of PVN neurons may begin around hatch in this bird. However, both the concentration and content of $\mathrm{GnIH}$ decreased temporarily in the diencephalon within a week after hatching. This finding is in agreement with a decrease in the expression of GnIH precursor mRNA on a unit weight of total RNA. Taken together, GnIH secretion may decrease temporarily after hatching. Subsequently, the content of GnIH in the diencephalon again increased progressively during posthatch development, due to an increase in the diencephalic tissue, and returned to the high level in adulthood. In addition, the present immunocytochemical study revealed an intense immunoreaction for $\mathrm{GnIH}$ in the medial and external layers of the $\mathrm{ME}$ in adult birds. It is therefore probable that GnIH may actually function in adulthood as well as around hatch.

The changes in circulating gonadotropins during development as well as after photostimulation have been documented in domestic birds (Follett 1976, Follett \& Robinson 1980, Tsutsui \& Ishii 1985, Tanabe et al. 1986), and their profiles may be in harmony with the present findings indicating developmental changes in $\mathrm{GnIH}$. According to Tanabe et al. (1986), the plasma concentration of luteinizing hormone (LH) was high at middle embryonic ages, decreased with advancing age, and remained at the low level at hatch in the chicken. We previously found that in the quail reared under the same photoperiodic condition (long-day photoperiods) of this study, plasma LH and follicle-stimulating hormone (FSH) were both low at hatch, increased rapidly during posthatch development reaching a peak prior to the maturation, and decreased thereafter when the gonad still continued growing (Tsutsui \& Ishii 1985, see Fig. 6). 


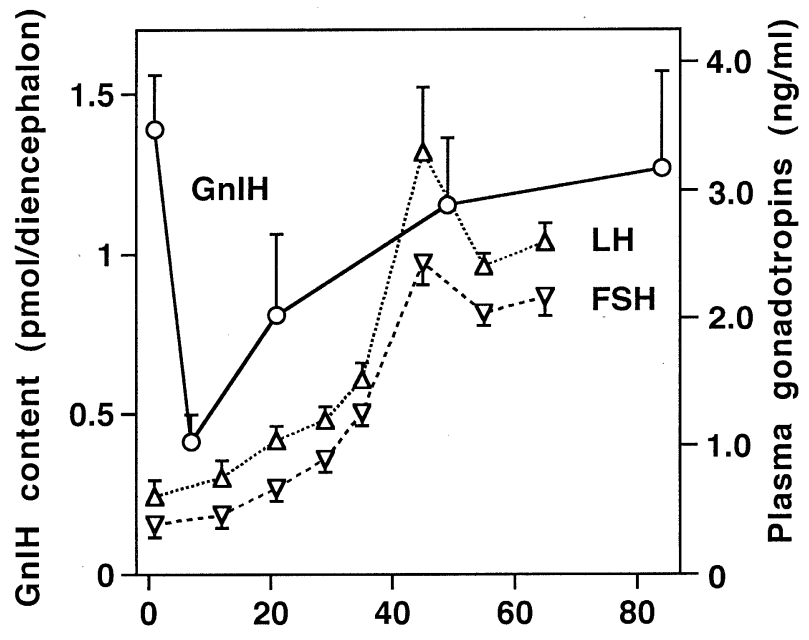

Age in posthatched days

Figure 6 An illustration showing changes in the diencephalic $\mathrm{GnlH}$ content observed in this study $(O)$ compared with changes in plasma gonadotropins $(\mathrm{LH}(\triangle), \mathrm{FSH}(\nabla))$ during posthatch development in the quails reared under the same long-day photoperiods (Tsutsui \& Ishii 1985). The concentrations of LH and FSH in the plasma were determined by the methods of Hattori \& Wakabayashi (1979) and Sakai \& Ishii (1980) respectively.

Therefore, circulating gonadotropins remained at the relatively lower level in adulthood (Tsutsui \& Ishii 1985). Such changes in circulating gonadotropins during development seem to be negatively correlated with those in GnIH observed in this study (Fig. 6). The secretion of gonadotropins may be regulated, at least partly, by the inhibitory action of GnIH. As GnIH was expressed highly in the PVN neurons projecting into the ME, it is probable that GnIH inhibits the secretion of gonadotropins around hatch. In addition, the inhibitory action of GnIH may be one of the main causes for the lower level of circulating gonadotropins in adulthood.

In birds, gonadal steroids are known to be a negative factor for the regulation of gonadotropin secretion. According to Ottinger \& Bakst (1981), circulating androgen was elevated on E13, the late embryonic period, through P3, the newly hatched period, in the male quail. We also found that in the male quail circulating testosterone was low after hatching and increased between P29 and P65 (Tsutsui \& Ishii 1985). These data also suggest that the secretion of gonadotropins during embryonic and posthatch development depends partly on negative feedback from gonadal steroids. From the present and previous studies, it is considered that not only gonadal steroids but also GnIH may act as negative factors on the regulation of gonadotropin secretion during development in the bird.

The present study provides the profiles of developmental changes in the expressions of $\mathrm{GnIH}$ precursor mRNA and the mature peptide GnIH in the quail diencephalon containing PVN neurons. The question arising from these findings is: what is the factor(s) that regulates $\mathrm{GnIH}$ expression in this neuron? Developmental changes in GnIH seem to be correlated with those in circulating androgen in male quails, since the increase in the diencephalic content of GnIH took place around hatch and in adulthood, concomitant with the increase in circulating testosterone (Ottinger \& Bakst 1981, Tsutsui \& Ishii 1985). Accordingly, gonadal steroids might contribute to $\mathrm{GnIH}$ induction during development. Future study is required to identify the factor(s) inducing $\mathrm{GnIH}$ expression in birds.

\section{Acknowledgements}

This work was supported in part by Grants-in-Aid for Scientific Research from the Ministry of Education, Science and Culture, Japan (12440233, 12894021, 13210101 and 15207007) to K T.

\section{References}

Bliss CI 1967 Statistics in Biology, vol 1, pp 253-257. New York: McGraw-Hill.

Follett BK 1976 Plasma follicle-stimulating hormone during photoperiodically induced sexual maturation in male Japanese quail. Journal of Endocrinology 69 117-126.

Follett BK \& Robinson JE 1980 Photoperiod and gonadotrophin secretion in birds. Seasonal reproduction in higher vertebrates. Progress in Reproductive Biology 5 39-61.

Hattori M \& Wakabayashi K 1979 Isoelectric focusing and gel filtration studies on the heterogeneity of avian pituitary luteinizing hormone. General and Comparative Endocrinology 39 215-221.

Li D, Tsutsui K, Muneoka Y, Minakata H \& Nomoto K 1996 An oviposition inducing peptide: isolation, localization, and function of avian galanin in the quail oviduct. Endocrinology 137 1618-1626.

Ottinger MA \& Bakst MR 1981 Peripheral androgen concentrations and testicular morphology in embryonic and young male Japanese quail. General and Comparative Endocrinology 43 170-177.

Sakai H \& Ishii S 1980 Isolation and characterization of chicken follicle-stimulating hormone. General and Comparative Endocrinology $421-8$.

Sakamoto H, Ubuka T, Kohchi C, Li D, Ukena K \& Tsutsui K 2000 Existence of galanin in lumbosacral sympathetic ganglionic neurons that project to the quail uterine oviduct. Endocrinology 141 4402-4412.

Satake H, Hisada M, Kawada T, Minakata H, Ukena K \& Tsutsui K 2001 Characterization of a cDNA encoding a novel avian hypothalamic neuropeptide exerting an inhibitory effect on gonadotropin release. Biochemical Journal 354 379-385.

Tanabe Y, Saito N \& Nakamura T 1986 Ontogenetic steroidogenesis by testes, ovary, and adrenals of embryonic and postembryonic chickens (Gallus domesticus). General and Comparative Endocrinology 63 456-463.

Tsutsui K \& Ishii S 1985 Hormonal mechanism for the induction of gonadotropin receptors in the developing testis of the Japanese quail. In Current Trends in Comparative Endocrinology, pp 761-762. Eds B Lofts \& WN Holmes. Hong Kong: Hong Kong University Press. 
Tsutsui K, Saigoh E, Ukena K, Teranishi H, Fujisawa Y, Kikuchi M, Ishii S \& Sharp PJ 2000 A novel avian hypothalamic peptide inhibiting gonadotropin release. Biochemical and Biophysical Research Communications 275 661-667.

Ubuka T, Sakamoto H, Li D, Ukena K \& Tsutsui K 2001

Developmental changes in galanin in lumbosacral sympathetic ganglionic neurons innervating the avian uterine oviduct and galanin induction by sex steroids. Journal of Endocrinology 170 357-368.
Ukena K, Ubuka T \& Tsutsui K 2003 Distribution of a novel avian gonadotropin-inhibitory hormone in the quail brain. Cell and Tissue Research 312 73-79.

Received 17 February 2003

Accepted 7 May 2003 